Radojka Vukčević

\title{
AMERIČKA KNJIŽEVNOST POSLE 9/11 - KNJIŽEVNOST „KRIZE”
}

Ovaj esej nudi pregled američke književnosti u prvoj polovini dvadesetprvog veka, takozvane književnosti nakon 11. septembra, odnosno književnosti krize. Tekst je organizovan prema književnim žanrovima i delima koje savremeni istoričari književnosti smatraju najrelevantnijim. Akcenat je stavljen na događaj od 11. septembra 2001. godine, kao najvažniji istorijski trenutak o kome je stvarana ova književnost. zija.

Ključne reči: 11. septembar, književnost, životni scenario, memoir, drama, poe-

Početak dvadeset prvog vijeka u Americi obilježila je finansijska nestabilnost koja je došla kao posledica sve većeg jaza između uprave i radnika, gubljenja radnih mjesta, sa sve nižim primanjima srednje i radničke klase. Ovaj proces počeo je u prethodne dvije decenije i, prvi put nakon Drugog svetskog rata, srednja klasa osjetila je nesigurnost i, čak, strah za golu egzistenciju. Stanje na tržištu natjeralo je veliki broj Amerikanaca da povuku svoj novac iz banaka i čuvaju ih u madracima, zbog čega je oko četrdeset posto finansijskih stručnjaka izgubilo posao. Pokazalo se da je prosperitet daleko ranjiviji nego što se dugo vjerovalo, što se odrazilo na finansijska kretanja u svijetu.

Nesigurnost i strah izazivala su sve češća bombardovanja američkih ambasada u svijetu (Najrobi i Dar es Salam, 1998). Godine 2000, Al Kaida je napala američki brod (US Cole), nakon čega Sjedinjene Države osnivaju kancelariju za anti-terorizam i po prvi put dopuštaju saradnju između državnih agencija kao što su CIA i FBI. Savremeni 
istoričari ove promjene opisuju kao tektonske promjene u istoriji, jer su prouzrokvale konflikt između Zapada i arapskih Muslimana, čemu su svakako išli u prilog harizma i vizija određenih pojedinaca, kao bin Ladena, na primjer. Ovo je prepoznao ne samo američki narod, već i mnogi pisci koji su u svojim djelima dali odgovore na ovaj dramatični istorijski trenutak.

Dogodio se i 11. septembar 2001. (9/11)! Milioni Amerikanaca izgubili su svoje voljene: više od 3000 ljudi. Prvi put su se u ovom vijeku suočili sa ogromnim gubicima, povredama, bolom i traumom neočekivanog napada na Svjetski trgovinski centar. Predstavljen i mnoštvom medijskih slika, utisnuo se u duše, poglede, um i svijest miliona ljudi. Ona, možda najbolnija slika prikazivala je očajničke pokušaje ljudi da se spasu skakanjem kroz prozore višespratnice. Ona koja ih je uznemiravala više od 100 dana pokazivala je pepeo u kome su se nalazili tragovi poginulih, dok se njegov miris širio na daleko. Svijest Amerikanaca se promijenila, a sam događaj našao je odjeke u svim žanrovima američke književnosti prve dekade 21. vijeka (književnosti 9/11), književnim i neknjiževnim.

Jedna od najčešće opisanih slika u književnosti 9/11 je sam pad ljudskih tijela niz kule u pepeo njujorških ulica. Vejn Dod (Wayne Dodd) (1930) u pjesmi „Treća kula” ("The Third Tower”) jasno i bolno prikazuje tu sliku: „Padajući zauvijek / iz budućnosti. / Padajući u sjećanje, / u odsustvo... / Avioni, ljudi, kule - padajući ispred / naših očiju...”. Pridružuje mu se još bolnijom slikom Gejl Grifin (Gail Griffin) u pjesmi „Kako je to moguće” ("How It Comes”). Naredni lajtmotif je slika pepela, koju posebno naglašavju Kimiko Han (Kimiko Hahn) (1955) i Džon Apdajk. Čuju se i glasovi Galavej Kinel (Galaway Kinnell) (1927-2014) i Džoj Harho. Ova tragedija ostavila je iza sebe mnoštvo životnih priča i srušenih snova, što su ključne riječi mnogih autora (Teri Tempest Vilijams, Lusil Klifton, Fred Moramarko (Terry Tempest Williams, Lucille Clifton, Fred Moramarco). Bol je tako dubok da je podijelio mišljenja da li uopšte nakon jedne ovakve tragedije imamo pravo na pjesničku riječ(Majkl Voters) (Michael Waters) (1949), da bi riječ, ipak, progovorila (Dejvid Vajs) (David Weiss) (1964). 
Oglasiti se u američkoj književnosti 9/11 nije bilo lako. Ipak, glasovi su se sve jače čuli i postepeno se definisala književnost traume i bola, ali i književnost političkih tonova. Svijet novinarstva morao je da odigra posebnu ulogu: da pomogne ljudima da naprave korak od traume do oporavka uz pomoć pitanja koja su se ticala identiteta pri čemu se, prema tvrđenju istraživača, moralo proći kroz tri faze jednog takvog procesa. One se odnose na povratak sigurnosti, ponovno sjećanje i oplakivanje i povezivanje sa običnim životom. Trebalo je ponovo dovesti u harmoniju postojeću stvarnost, jer pisci se nisu samo obraćali pojedincu već cijelom društvu. Otvorila se velika tema kojom su se, neposredno nakon perioda tišine, bavili gotovo svi: rat i američka nevinost. Mnogima se pridružila i Erika Džong koja je izjavila da su 9/11 Amerikanci izgubili sigurnost i postali dio ranjive ljudske rase. Jedno od mnogih pitanja na koje je trebalo odgovoriti glasilo je: kako upisati $9 / 11$ u američku istoriju?

Američka književnost dala je svoj odgovor poezijom i kratkim pričama u prvoj dekadi s očekivanjem da će se ostali žanrovi (memoari i romani) značajnije razviti u narednoj dekadi. Kritika je ovaj proces prepoznala ranije, definisanjem novog žanra: roman 9/11 ili post-9/11 roman. Istina je negdje na sredini, jer je značajan korpus istaknutih romana na temu 9/11 uglavnom nastao u periodu od 2007-2009. Savremeni istraživači prepoznaju i određeni obrazac koji se ogleda u nadrealnoj atmosferi i ponašanju likova (besciljnost, tehnološka bespomoćnost, svijet bez osude), fragmentaciji, ukidanju realnosti, odsustvu sveznavajućeg naratora ili posmatrača. Pisci zauzimaju iracionalan ugao posmatranja, a takvi su i radnja i mjesto odvijanja: u svijetu nakon $9 / 11$ ne vlada nikakav red.

Odgovor na takav svijet daju najistaknutiji romani 9/11, od kojih je savremena kritika na prvo mjesto postavila roman Vrt posljednjih dana (The Garden of Last Days, 2008) Andrea Dubsa III (Andre Dubus III) (1959), čiji je jedan od glavnih likova terorista Basam. U potrazi za ljubavlju i vjerom, on otvara mnoštvo savremnih pitanja. Pol Oster (Čovjek u mraku, 2008) ima potpuno drugačiji pristup ovoj temi: nema lika teroriste, $9 / 11$ se nikada nije ni dogodio; priča je veoma fragmentarna; obiluje narativnom samo-ironijom; roman predstavlja metafo- 
ru svih užasnih priča, pa i 9/11. Sličan izbor pravi Džozef O’Nil (Joseph O’Neill) (1964) u svom romanu Ničija zemlja (Neitherland, 2008) u kome samo pominje kako se zbog $9 / 11$ otrovao Njujork i prati razvoj jedne složene imigrantske priče. Pitanja razlike i drugosti u kulturi Sjedinjenih Država istražuje i Suzan Čoj (Susan Choi) (1969) u romanu Osoba od interesa (A Person of Interest, 2008). Kulturološki mikrokozm definišu ambicija, moć, zavist i nasilje, pa, ipak, autorka ovog složenog romana uspijeva da romanu dâ srećan završetak i pruži čitaocima nadu da uvijek postoji rešenje, čak iako ste azijski Amerikanac i, pored toga, neopravdano optuženi terorista. Elen Gilkrist (Ellen Gilchrist) (1935̆) piše roman Opasno doba (A Dangerous Age, 2008) koji je čvršće povezan sa tragedijom $9 / 11$, jer vjerenik jedne od tri junakinje gine u Svjetskom trgovinskom centru par nedelja prije njihovog vjenčanja. Autorka prati njihovu moguću budućnost koja ide od tragedije ka metafori ponovnog rođenja, kada se nakon četiri godine rađa Olivijino dijete. Roman ima složenu narativnu strukturu i pokušava da odgovori na pitanja ratova van Amerike, boje kože u Americi i pitanja budućnosti svijeta. Dvije godine kasnije pojavljuje se roman Sju Miler (Sue Miller) (1943) Ograničena obala jezera (The Lake Shore Limited), u kome autorka fikcionalizuje emocionalni haos 9/11. Roman, između ostalog, stavlja u fokus istraživanja čovjekovu sposobnost da očuva optimizam, uprkos nevoljama koje ga mogu snaći.

Vrijedi pomenuti i roman Imperatorova djeca (The Emperor's Children, 2006) koji je Kler Mesud (Claire Messud) (1966) poslužio da istraži senzibilitet grupe. U romanu Ekstremno glasno i nevjerovatno blisko (Extremely Loud and Incredibly Close, 2005゙), Džonatan Safran For (Jonathan Safran Foer) (1977) ispituje drugost, bazirajući roman na dokumentarnom i nevinom liku devetogodišnjeg dječaka, da bi, na kraju, pokazao da je komunikacija moguća. Budući da je to bio prvi roman nakon 9/11, imao je odličnu recepciju, a naročito od 2012, nakon što je snimljen film po njegovim motivima. Istoričari savremene književnosti uočili su izvjesne zajedničke naratološke strategije u pomenutim romanima: likovi terorista tek su dati samo u obrisima i često bez imena; najčešće su sa Srednjeg istoka, nisu Hrišćani, ali se ne 
kaže ni da su Muslimani; obično su mladi i donekle zbunjeni: krajnji rezultat je strah.

Razloge za strah pruža i postmodernistička pometnja, prisutna u nekim od romana 9/11. Pometnja je prisutna pogotovo kod onih pisaca koji su u padu kula prepoznali veliku američku temu koja se prati od samih početaka i pokušaja da se definiše kao nacionalna književnost: pad iz svijeta nevinosti u svijet iskustva. Pad kula izazvao je osjećaj jaza između ondašnjeg vremena i vremena poslije, koji mnogi doživljavaju kao ambis koji se teško može savladati. Gubitak privatnog, ličnog, povratak „puste zemlje”, strah, otpor i predavanje ekstremnom definišu post-9/11 svijet u mnogim djelima američke književnosti 9/11, ili književnosti krize, kako je definišu neki savremeni izučavaoci. Stari način mišljenja je uništen i pisci su dobili zadatak da odgovore na izazov novog. Kao da se ponovo javio stari poznati bol promjene, ali u potpuno drugačijoj odori! Kao da je došao trenutak da se prepozna tijesna veza između teorijskog i fikcionalnog, gdje je, često, tekst prije simptom nego dijagnoza, stav da se trauma teško može izraziti riječima, razumjeti.

Novi događaji i novo razumijevanje svijeta zatražili su drugačiju svijest, nove ideološke strukture i imaginaciju koja cee ih asimilovati i izraziti. Koliko nove, pitaju se i savremeni istraživači i s pravom zaključuju da, ipak, nema poetički suštinski velikih pomaka: u književnosti 9/11 često se ponavljaju konvencionalne narativne paterne, fragmentiranost, odnos ličnog i političkog, privatnog i javnog, opresora i žrtve. Prisutna su politička retorika: patriotizam, demokratija, lojalnost, sloboda, neizrecivost, grad i novac kao tema, Njujork i svijet, pluralnost kao imperativ, globalni kapitalizam, hibridni prostor, potraga, sjećanja, inicijacija, kontroverzni termin „post-rasna književnost”, lično prepoznavanje bola promjene, ali ne onoliko kolektivno koliko se eksplicitno nagovještavalo, susret sa drugačijim, pri čemu je komunizam zamijenjen Islamom. Prikazuju se slika Amerike kao granične teritorije, poroznost granica, odnosi moći, roda, etniciteta, političke pripadnosti, književnost kao konstantan proces preispitivanja. 


\section{Proza}

Američka prozna djela u ovom periodu odgovaraju na mnoge već pomenute teme sa akcentom na 9/11, eksperimentušići i dalje sa mogućnostima jezika. Sve do pojave DeLilovog djela Point Omega (Point Omega, 2010) vjerovalo se da je Padač (Falling Man, 2007) sve što je ovaj pisac imao da nam kaže na ovu temu. Sam događaj je bolniji nego što se i može pretpostaviti: DeLilo smješta radnju romana u pustinji da bi naglasio pustoš iznad Njujorka i na samoj zemlji, užase uništenja od strane ljudske ruke. U samom fokusu romana je mučno meditiranje o vremenu i životu. DeLilo su pridružuje jednom broju istaknutih autora koji na sličan način prilaze ovoj temi: Džon Irving sa svojim romanom Sinoć u vijugavoj rijeci (Last Night in Twisted River, 2009); Kormak Makarti sa post-apokaliptičkim romanom Put (The Road, 2006), Doktorov sa romanom Marš (March, 2005), i Džošua Feris (Joshua Ferris) (1974) sa veoma dobro prihvaćenim i nagrađenim prvim romanom Tada smo došli do kraja (Then We Came to the End, 2007), kao i enigmatičnim drugim romanom Neimenovani (The Unnamed, 2010).

Promišljanje raznih životnih aspekata tema je i istaknute književnice Džejn Smajli (Jane Smiley) (1949) u djelu Privatan život, roman (Private Life. A Novel, 2010) koji ispituje tegobe braka dvoje neravnopravnih ljudi da bi nam na kraju ponudila dilemu da li je rešenje razvod ili je to uklanjanje žene kao dokaza da monogamija lagano umire. Ričard Pauers (Richard Powers) (1957) u romanu Dozivač eha (The Echo Maker, 2006) opisuje drugačije ropstvo, postavljajući filozofsko pitanje o odnosu mozga, uma i kraja čovjeka. Pauers ispituje slična filozofska pitanja i u romanu Velikodušnost (Generosity, 2010), koji savremena kritika opisuje transparentnijim prostorom u kome se jasnije definiše odnos realnog i zamišljenog, slobodnog i zavisnog. Džonatan Frenzen (Jonathan Franzen) (1959) piše dva romana na temu 9/11, koja neki istoričari svrstavaju u moralnu prozu, Korekcije (The Corrections, 2001) i roman ironičnog naslova Sloboda (Freedom, 2010) u koji uvodi i temu „zaštićenih” Jevreja da bi samo pokazao kako je sloboda puka 
iluzija. Izdvojićemo i glas promišljanja Dejvida Fostera Volasa (David Foster Wallace) (1962-2008) i njegov povratak ,realnom” u romanima Zaborav (Oblivion, 2004) i Blijedi kralj (The Pale King, 2011).

Ratna tematika sa akcentom na ličnom široko je zastupljena u savremenoj američkoj književnosti, pogotovo od vijetnmskog i korejskog rata, i prisutna je u mnogim romanima iz ovog perioda. Tri takva romana ušla su u uži izbor za Pulicerovu nagradu: Smeće rata (War Trash, 2005) Ha Jina (Ha Jin) (1956); Stablo od dima (Tree of Smoke, 2007) Denisa Džonsona (Denis H. Johnson) (1949-2017); Gubitnici (The Surrendered, 2008) Ceng-Rej Lija (Chang-Rae Lee) (1965). Smeće rata ispituje period od 1950 do 1953. sa radnjom koja je smještena u Americi i njenim vojnim kampovima. Stablo od dima dovodi u pitanje smisao ubijanja i rata uopšte, fokusirajući se na period nakon ubistva Kenedija. Gubitnici se vezuju za korejski rat i stavljaju akcenat na bijedu i duh rata, likove uhvaćene u grču emocionalnih konflikata. Vredi pomenuti još dva nenagrađena romana: roman Dejvida Vroblevskog (David Wroblewski) (1959) Priča o Edgaru Sotelu (The Story of Edgar Sawtelle, 2008) i roman Džejn En Filips (Jane Anne Philips) (1952) Ševa $i$ Termit (Lark \& Termit, 2009). Priča o Edgaru Sotelu počinje Prologom koji je smješten u Južnoj Koreji 1952, a opisuje posjetu botaničkoj radnji jednog američkog vojnika u Vijetnamu, da bi se kasnije pratila sudbina adolescenta, Edgara Sotela, kome je Bog oduzeo moć govora. Roman posebno ubjedljivo prikazuje njegov svijet tišine. Roman Ševa $i$ termit takođe ispituje svijet tišine, ali ovog puta djeteta Termita u zapadnoj Virdžiniji i svijet njegovog oca Roberta u Vijetnamu. Filip Rot nastavio je intenzivno da stvara i u ovom periodu kada piše roman u kome on igra glavnu ulogu: Zavjera protiv Amerike (Plot Against America, 2004); i niz kraćih romana Svako (Everyman, 2006); Ogorčenost (Indignation, 2008); Poniženje (The Humbling, 2009) i Nemeza (Nemesis, 2010). U Zavjeri protiv Amerike, Rot postavlja neka ozbiljna pitanja koja se tiču prirode američke demokratije i američke politike, uopšte. Susret sa sopstvenom i opštom prolaznošću Rot ispituje u romanu Svako, gdje ukazuje bolan put ka čovjekovom kraju bez vjere u Boga. 
Nekoliko književnica koje su osvojile značajne književne nagrade pokazale su još jednu jaku tendenciju u savremnoj američkoj književnosti: sklonost ka poetskom realizmu. Izdvajaju se: Elizabet Straut (Elizabeth Strout) (1956), koja je osvojila Pulicerovu nagradu za književnost 2009. za roman Oliv Kitriď̌ (Olive Kitteridge, 2009), koji otkriva tajanstvenu složenost života kada ostanete sami; Lujza Erdrih (Louise Erdrich) (1954) sa romanom Pohara golubova (The Plague of Doves, 2008) i Kristina Šat (Christine Schutt) (1948) sa Svim dušama (All Souls). Kritika pronalazi poetičku vezu između Strautove i romana Marš (March, 2005) Džeraldine Bruks (Geraldine Brooks) (1955) dobitnice Pulicerove nagrade za 2006. Ona nastavlja da istražuje svijet žene u svom bestseler romanu Ljudi od knjige (People of the Book, 2008). Tragovi slične potrage mogu se pronaći u romanu Ejmi Blum (Amy Bloom) (1953), Daleko (Away, 2007). Post-traumatsko stanje američke nacije nakon 9/11 ispituje Lori Mur (Lorrie Moore) (1957) u romanu Kapija stepenica (A Gate at the Stairs, 2009). Iste godine pojavljuje se roman Minrouz Gvin (Minrose Gwin) (1945), Kraljica Palmire (The Queen of Palmira, 2010), s ciljem da pokuša da odgovori na složenost rasnih odnosa na američkom Jugu.

Neki od savremenih romana, dobitnika Pulicerove nagrade, mogu se, prema mišljenju nekih istraživača, nazvati i „pastoralnim”, kao, na primjer, roman Ričarda Rusoa (Richard Russo) (1949) Pada imperija (Empire Falls, 2001), dobitnik ove nagrade 2002. godine, a koji neki istoričari svrstavaju i među romane moralne fikcije. Sedam godina kasnije, on piše Taj stari magični rt (The Old Cape Magic, 2009), roman sa nježnijim razrešenjem. Iz ove grupe mogli bismo izdvojiti roman poetske proze, meditaciju o smrti, Tinkers (Tinkers, 2007) Pola Hardinga (Paul Harding) (1967) koji je osvojio Pulicerovu nagradu godinu dana kasnije. Neophodno je pomenuti roman Dani Džona Henrija (John Henry Days, 2009) afro-američkog pisca Kolsona Vajtheda (Colson Whitehead) (1969), koji ispitijući američku srednju klasu spaja tradiciju crnačke pobune i postmoderne poetike. Njemu se pridružuje Stiven L. Karter (Stephen L. Carter) (1954) u romanima političkih intriga i u istorijskim romanima. Savjet palate (Palace Council, 2008) stavlja u centar nemogućnost komunikacije crnaca i bijelaca u perio- 
du od 30 mjeseci početkom 1950ih. Od istaknutih pisaca sa američkog Juga izdvojićemo Peta Konroja (Pat Conroy) (1945) i njegov roman Južno od široke ulice (South of Broad) iz 2009. u kome prati sudbinu nekoliko likova iz njegovih prethodnih romana.

Haled Hoseini (Khaled Hosseini) (1965), pisac avganistanskoameričkog porijekla, fascinirao je 2003. čitalačku publiku ne samo u Americi, već i širom svijeta, romanom Lovac na zmajeve (The KiteRunner). Ozbiljna i složena drama o prijateljstvu, po mišljenju nekih savremnih istraživača, priziva i percepciju bajkovitog kraja. Isto tako svježu perspektivu o mogućnostima američke književnosti u ovoj dekadi ponudila je Dženifer Egan (Jennifer Egan) (1962), dobitnica Pulicerove nagrade za 2011. godinu, objavljivanjem romana Posjeta iz Gun Skvoda (A Visitfrom the Goon Squad). U povremeno haotičnoj i fragmentiranoj priči o životu nekoliko likova, ona kombinuje elemente grafičkog narativa da bi ih predstavila kao disfunkcionalne, izvan pravila o američkom snu. Svježinu unosi i Dejvid Antin (David Antin) (1932) naglašavanjem uloge sna i želje, pri čemu se sama naracija pomjera na drugo mjesto. To posebno primjenjuje u romanu Radikalna koherencija (Radical Coherency, 2011).

Povezanost sna, narativa i sjećanja savremena kritika prepoznaje i u djelima još tri savremena autora: Poznati svijet (The Known World, 2003) Edvarda P. Džounsa (Edward P. Jones) (1951); Midlseks (Middlesex, 2002) Džefrija Judženideza (Jeffrey Eugenides) (1960) i u nekolika romana Toni Morison: Ljubav (Love, 2003); Milosrde (Mercy, 2008), Dom (Home, 2012), Bog djeci pomaže (God Help the Child, 2015). Poznati svijet ispituje svijet robova kroz fragmentarnu prozu sa dovoljno detalja da bi ga čitaoci prihvatili kao prozu koja se čita sa posebnom pažnjom. Midlseks je privukao pažnju čitalačke publike zbog teme koja istražuje seksualne preference kroz neki vid komičnog epa. Ljubav ispituje borbu između polova i snagu muškarca i njihovu pretpostavljenu nadmoć kroz priču o Bilu Koziju (Bill Cosey) i nekoliko žena koje ga vole. Milosrde se vraća na temu ropstva i pokušaj jedne crnkinje da spasi svoju kćerku da ne bude ropkinja, pri čemu Toni Morison na kraju romana ne nudi nadu, kao što to čini u svom remek djelu Voljena. I roman Dom ispituje čovjekovu patnju ali ovog puta tokom 
Korejskog rata, njegovu nehumanost, i snagu nekolika ženska lika da uzmu život u svoje ruke.

\section{MEMOARI I ŽIVOTNI SCENARIO}

Nefikcionalna proza ima posebno mjesto na kraju prošlog i početkom ovog vijeka, naglašavajući sve više zamagljivanje granica između fikcije i mnogih drugih vidova nefikcije (memoari, autobiografija, „Životni scenario”, magazin, subjektivno novinarstvo, narativni eksperimenti u svim oblastima). Iako se tragovi mogu pratiti unazad četrdesetak godina, od „novog novinarstva” preko predstavnika bit generacije, povratka usmene tradicije, tek u novije vrijeme mogu se prepoznati novi vidovi fikcionalizovanih memoara i sličnih žanrova. Posmatrano istorijski, kritika uzima kao ključnu godinu 1970, kada se pojavila knjiga novinara Stadsa Terkela (Studs Terkel) (1912-2008) Teška vremena: usmena istorija velike depresije (Hard Times: An Oral History of the Great Depression). Usmena istorija se izučava dok, istovremeno, postaje sve popularniji žanr, ali sada u vidu intervjua. Dekadu kasnije, Terkelov polubrat, Tobajas Vulf (Tobias Wolff) (1945) napisao je knjigu zasnovanu na životu majke, Život ovog dječaka (This Boy's Life, 1989), koja je imala odličnu recepciju i od strane publike i kritike. Godine 19\%4, izdvojila se knjiga Eni Dilard (Annie Dillard) (1945) Hodočasnik na Tinker Kriku (Pilgrim at Tinker Creek), koja je naredne godine dobila Pulicerovu nagradu za nefikcionalne tekstove. Knjiga je privukla čitaoce i zbog ekološkog pristupa, dok je kritika isticala snagu njenog pouzdanog ženskog glasa koji se bori za očuvanje životne sredine na američkom Jugu. Sam naslov evocira mnoge već definisane teme u istoriji američke književnosti.

Savremeni istraživači prepoznaju u terminu životni scenario (life-writing) sveoubuhvatnost raznih savremenih proznih izraza (memoare, biografije, kao i savremene hibridne forme kao što su grafički romani, grafički memoari i autobiografska proza). Sam termin uključuje i lično i tuđe iskustvo: on ne evocira isključivo onu oslobađajuću snagu proze, već i sposobnost da se stvaraju alternativni svjetovi i 
prepoznaju dokumentarne i performativne dimenzije ispovjedanja i svjedočanstva, njihova etička snaga.

Porodične priče i biografije inspirisale su veliki broj književnica i u narednih par dekada, kada dolazi do „feminizacije književnog tržišta" kad se prepoznaje prava eksplozija nefikcionalnih tekstova, pogotovo memoara, koji uglavnom u sam centar stavljaju sjećanja na porodicu. Između mnogih, izdvajaju se Žestoki dodaci, memoari (Fierce Attachments, A Memoir, 1987) Vivijan Gornik (Vivian Gornic (1935); Tata, jedva da smo te i poznavali (Daddy, We Hardly Knew You, 1989) Džermejn Grir (Germaine Greer) (1939); Debora, Golda, i ja: biti žena i Jevrejka u Americi (Deborah, Golda, and me: Being Female and Jewish in America, 1991); Ponos jedne porodice: četiri generacije obojenih Amerikanki (Pride of Family: Four Generations of American Women of Color, 1991) Karol Ajon (Carol Ione) (1937); Alva Mirdal: memoari jedne kćerke (Alva Myrdal: A Daugher's Memoir, 1991) Sisile Bok (Sissela Bok) (1934); Djevojka, ućutkana (Girl, Interrupted, 1993); Klub Lažova (The Liers's Club, 1995) Meri Kar (Mary Karr) (1955); Prozačkanacija (Prozac Nation, 1994); i Srećan (Lucky, 1999) Alis Sebold (Alice Sebold) (1963).

Bol utiče i na stvaranje podžanra - memoara o bolesti koji privlače značajnu čitalačku publiku. Ovaj podžanr ne izaziva privlačnost samo zbog mogućeg samosaželjenja, već najčešće zbog njihovih književnih odlika, prisustva elemenata humora i drugog. Među ovim autorima izdvaja se Marija Hornbaher (Marya Hornbacher) (1974) sa svojim djelom Protraćeno, memoari o anaoreksiji i bulimiji (Wasted, A Memoir of Anorexia and Bulimia, 1998). Ovo djelo nastalo je pod uticajem memoara Nensi Meirs (Nancy Mairs) (1943) Običan tekst: otkrivanje života jedne žene (Plaintext: Deciphering a Woman's Life, 1986) i Do pojasa u svijetu: jedan život medu neinvalidima (Waist-High in the World: A Life Among the Nondisabled, 1997) i pogotovo djela Odri Lord (Audre Lorde) (1934-1992) Dnevnici o raku (The Cancer Journals, 1980) koje naglašava i fizički i psihički bol.

U prvoj dekadi 21. vijeka izdvaja se nekoliko memoara onih autora koji su, uglavnom, prozni pisci i koji su napisali samo jednu takvu knjigu. Tako, Alan Šapiro (Alan Shapiro) (1952) piše knjigu memoara, 
Bdenje (Vigil, 1977), o gubitku bitke svoje sestre Bet sa kancerom, kroz neki vid poetske proze. Pridružuje mu se Meri Gordon (Mary Gordon) (1949) sa svojim djelom Moja majka se vrti u krug (Circling My Mother, 2007), potom DeSalvo sa svojim memoarima Bez daha (Breathless: An Asthma Jurnal, 1998), dok Dejv Egers (Dave Eggers) (1970) od svojih inicijalnih memoara, Srceparajuće djelo posustalog genija (A Heartbreaking Work of Staggering Genius, 2000) pravi konvencionalan i pomalo humoristički roman. Na sličan način povezana su dva memoara o gubitku već istaknute autorke Džoan Didion (Joan Didion), Godina magïskog rašmišljanja (The Years of Mafical Thinking, 2005) i Plave noći (Blue Nights, 2011), dok se pojavljuju jednako uspješni memoari o gubitku i udovištvu Kej Redfild Džejmison (Kay Redfield Jamison) (1946), Ništa nije bilo isto (Nothing Was the Same, 2009), i Džojs Kerol Outs (Joyce Carol Oates) (1938) (A Widow's Story: A Memoir, 2011).

Sve pomenute i slične memoare povezuje ranjivost, što privlači čitalačku publiku željnu slike realnosti života. Oni istovremeno postaju predmet mnogih studija koji je istražuju iz različitih uglova (istorija, biologija...). Pomenućemo antropološku studiju Rut Behar (Ruth Behar) (1956) Ranjivi posmatrač: antropologija koja slama srce (The Vulnarable Observer: Anthropology That Breaks Your Heart, 1997) u kojoj ispituje onu tanku liniju između strasti i intelekta, analize i subjektivnosti, etnografije i autobiografije, umjetnosti i života. U takva djela spadaju i didaktički komentari o uzgoju hrane koji prate peti roman Barbare Kingsolver (Barbara Kingsolver) (1955) Životinja, povrće, čudo: godina prehranjivanja (Animal, Vegetable, Miracle: A Year of Food Life, 2007), kao i bestseler Džonatana Safrana Fora Jesti životinje (Eating Animals, 2009), koji govore o moralnoj strani konzumiranja životinja.

Obiman korpus priča o životu nastao je i od strane autora koji su stekli ugled kao etnički pisci: memoari Džulije Alvarez (Julia Alvarez) (1950) Jo! (Yo!, 1997), potom Ples bez riječi (Silent Dancing, 2005), Džudit Ortiz Kofer (Judith Ortiz Cofer) (1952). Izdvojićemo i memoare zahvaljujući kojima je stekao ugled Ričard Rodrigez (Richard Rodriguez) (1944): Glad sjećanja: obrazovanje Ričarda Rodrigeza (Hunger of Memory: The Education of Richard Rodriguez, 1982) i Dani obaveza: 
rasprava sa mojim meksičkim ocem (Days of Obligation: An Argument with my Mexican Father, 1992). Neki kritičari prepoznaju u memoarima i još jedan sloj značenja: imigrantsko pismo sa migracijama u centru. Ipak, na početku milenijuma izdvajaju se i oni memoari koji opisuju borbu sa sobom, kao, na primjer, bestseler Džejmsa Freja (James Frey) (1969) Milion komadića (A Million Little Pieces, 2003), njegovo oslobađanje od zavisnosti od droge, seksa i alkohola i Korekcije (The Corrections) Džonatana Frenzena. I, na kraju, da dodamo još nešto: Dejv Egers (Dave Eggers) uspijeva da definiše još jedan vid memoara u djelima Šta je šta (What is the What, 2005), kombinaciji autobiografije i romana, i Zajtun (Zeitoun, 2009), koji na osnovu savremene usmene istorije istražuje raznorodne teme, kao što su orkan Katrina, poplave i rasne predrasude sa akcentom na post-traumatskom stresu.

\section{DRAMA}

Drame inspirisane 9/11, ključnim događajem u Americi u dvadesetprvom vijeku, nisu izuzetne po obimu, ali ni po broju izvođenja. Neki istraživači ovo objašnjavaju sve jačom ulogom medija u pričanju priče i elektronske dostupnosti prenosa izvođenja komada, zbog čega konstantno pada broj redovnih posjetilaca Brodveja. Oni tvrde da je sve manji broj dramskih djela od strane manjina po bilo kom ključu, tako da rasa ili seksualni izbor sada ne predstavljaju više istaknutu kategoriju. Uprkos tome, nacionalne nagrade za prve komade i dalje se dodjeljuju. Pomenimo dramu Dokaz (Proof) Dejvida Oberna (David Auburn) (1969), koja je nagrađena 2001; Dag Rajtovu (Doug Wright) (1962) dramu Ja sam svoja sopstvena žena (IAm My Own Wife, 2004) i Džon Petrik Šenlijevu (John Patrick Shanley) (1950) dramu Sumnja: parabola (Doubt: A Parable, 2005). Akcenat se pomjera na odnose između likova, intimnost i tekstove koji ulaze u finalnu trku za Pulicerevu nagradu, kao što su dva komada feminističke autorke Sare Rul (Sarah Ruhl) (1974) Čista kuća i U sledećoj sobi (The Clean House, 2005, In the next Room, 2010). Vredi pomenuti još dva komada Trejsi Lets (Tracy Letts) (1965) Čovjek iz Nebraske (Man From Nebrasca, 2004) 
koji je nominovan za Pulicerovu nagradu i Okrug Osaž (Osage County), komad koji je tu nagradu osvojio 2008. godine.

Ipak, moramo izdvojiti još neka djela, prije svih dramu En Nelson (Anne Nelson) (1969) Momci (The Guys, 2001) zbog izuzetne popularnosti. Drama priziva sjećanja dva glavna lika, vatrogasca Nika koji je pukim slučajem izbjegao smrt, i Džin, novinarke iz Oklahome, koja ne može da se suoči sa tragičnim ishodom 9/11, da bi na kraju doživio svojevrsnu katarzu, što se očekuje i od publike. Preispituje se kraj postmodernog doba, koncept istorije, ali niko ne pokušava da razumije smisao same krize tog trenutka: akcenat je na posledicama, a ne na uzroku. To ne oduzima snagu ovom komadu, krajnje jednostavnom, koji vjeruje u „čuda” i moć pripovjedanja, zaključuje savremena kritika. No, uzima joj jedan dio, budući da ne uspijeva da razvije likove dalje od stereotipova. I to se da oprostiti, zbog čega je lako složiti se sa istraživačima koji u ovom komadu vide nastavak dobre američke tradicije populizma, koja stavlja akcenat na „običnom”, umjesto na individualnom.

Drama Milosrdno mjesto (The Mercy Seat, 2002) Nila Labjuta (Neal LaBute) (1963) podsjeća na dramu Momci: ima dva lika, radnja se odvija u Njujorku odmah nakon 9/11 i ne otvaraju se pitanja uzroka terorizma. Umjesto njih, ova drama ispituje moć i izdaju kroz priču o preljubi i opstanku - neki vid hamletovske dileme. Pisac, po mišljenju kritike, ipak zauzima politički stav u odnosu na politiku ličnih i seksualnih odnosa, što naziva posebnim vidom ličnog terorizma, ratom između zaljubljenih, istovremeno pokazujući u kojoj mjeri ljudska sebičnost pojedinca može nadvladati trenutak nacionalne nesebičnosti.

Krizu 9/11 uskoro će zamijeniti dugotrajnija trauma kao posledica „rata sa terorom”. Ovu temu ispitivaće i arapski Amerikanac Jusuf El Gvindi (Yussef El Guindi), u drami Potiljak (The Back of the Thro$a t, 2005)$ koji obiluje elementima crnog humora i ozbiljnosti. I ovo je komad u kome se ispituju moć i jezik, nevinost i krivica. Pisac se poigrava sa jezikom konstruišući i dekonstruišući odnose između tri lika (pisca i dva FBI islednika). Krivica/nevinost glavnog lika, ne može se dokazati, jer se uzimaju sama priča i ugao naratora kao odlučujući. Istorija je dio priče, stvarnost konstruišu ljudi od moći: ona je stvar 
jezika. Jezik kao sredstvo komunikacije, pokazuju i dramski pisac i kritika, u ovoj drami postaje jezik koji ima moć: on je oružje u ratu između terorista i antiterorista, važan činilac u rekonstrukciji realnosti i destrukciji realnog.

Ipak, život mora da se nastavi i nakon 9/11, koji i dalje određuje sudbinu multikulturalne Amerike i istovremeno pojačava njihovu svijest o pripadanju Americi i, posebno, mjestu (Njujorku), ali i prolaznosti svega ostalog. Ovaj stav zauzima Kristofer Sin (Christopher Shinn) (1979) u komadu sa petnaest likova Gdje mi to stvarno živimo? (Where Do We Live, 2003). Upotrebom savremenih dramskih sredstava, konstantnim promjenama scena, preklapanjem radnje i dijaloga, on uspijeva da definiše mjesto dešavanja radnje kao još jednu graničnu teritoriju na kojoj se ljudi potpuno drugačijeg kulturološkog, klasnog i etničkog osnova srijeću (bijelci, crnci, homoseksualci, dileri droga), razgovaraju, raspravljaju i ulaze u međusobne odnose. Glavnu prijetnju savremena kritika prepoznaje na nekolika nivoa: od terorizma do uskogrudog nacionalizma, od nasilja do netrpeljivosti, od bombardovanja do socijalne politike koja ih razdvaja. Radi se o suptilnoj analizi grada, društva u krizi i njegovom potencijalu, komadu čiji završetak ukazuje na tijesnu vezu između savremenosti i jasno zacrtane sudbine.

Adrijano Šaplin (Adriano Shaplin-) (1979) u post-9/11 drami Bokser specijalista (Pugilist Specialist, 2003) insistira na neodređenosti, fragmentarnom svijetu, nemogućnosti komunikacije, svijetu bez meta i istorije, prijetnji, nasilju i konfuziji. Teško da je uopšte moguće protumačiti jezičke i dramske znakove, dijalozi četiri marinca jedva se mogu pratiti, ipak publika stalno pokušava da dešifruje tajnovite poruke. Ovo vodi savremenu kritiku da zaključi da se ovdje radi o dekonstrukciji jezika nacionalizma koji Šaplin zamjenjuje dramskim jezikom post-postmodernističke neodređenosti, onim jezikom koji stalno izaziva diskurs „rata protiv terorizma” (Irak), što ga čini jednim od najsuptilnijih i najsubverzivnijih komada istovremeno.

Bog pakla (The God of Hell) Sema Šeparda ispituje jednu od njegovih omiljenih tema: nestajanje pravog Zapada i pojavu novog Zapada sa izraženim potrošačkim i koruptivnim mentalitetom. Prelomni dogadaj je 9/11 i njegove posledice: destrukcija Amerike, ne toliko od 
strane terorizma, koliko od kontraterorizma. Šepard namjerno uzima za glavne likove par sa srednjeg Zapada, da bi pokazao kako se tamo ništa ne dešava, čime je i, prema mišljenju kritike, pokazao kako se američki san sada sanja kao nadrealna mora koja istovremeno priziva stari mit o američkom Zapadu i podriva ga. Glavni likovi, Ema i Frenk, postaju žrtve ruralnog prostora, a ne odabrani ljudi na putu ka spasenju, zbog čega je njihov Bog - Bog pakla.

Sem Šepard nastavlja sa svojim produkcijama i 2007. godine piše Šutiranje mrtvog konja (Kicking a Dead Horse), a 2009. Doba mjeseca (Ages of the Moon). Pridružuju mu se mnogi već istaknuti pisci: Edvard Olbi sa komadima koji su ušli kao finalisti za Pulicerovu nagradu: Koza ili ko je Silvija? (The Goat or Who Is Sylvia?, 2003) i Komad o bebi (The Play About the Baby, 2001). Dva značajna komada piše Dejvid Henri Hveng (David Henry Hwang) (1957), od kojih je kandidat za Pulicera 2008. godine bio komad Žuto lice (Yellow Face), dok je Kingliš (Chinglish) otvorio sezonu 2011-2012. Sličan uspjeh doživio je Džon Guari (John Guare) (1938) čiji je komad Slobodan obojeni čovjek (A Free Man of Color) ušao u finale za Pulicera 2011, dok je Kuća puna plavog lišća (The House of Blue Leaves) ponovo postavljena 2011. Pomenimo još tri autora koji su ovoj dekadi osvojili Pulicerovu nagradu: Nilo Kruz (Nilo Cruz) (1960) za komad Ana u Tropskom pojasu (Anna in the Tropics, 2003); Dejvid Lindzi Aber (David Lyndsay-Abaire) (1969) za Zečju rupu (Rabbit Hole, 2007); i, Lin Notidž (Lynn Nottage) (1964) za dramu Uništeni (Ruined, 2009).

Moramo naglasiti da u ovoj deceniji dominira i dramski glas $\mathrm{Su}^{-}$ zan-Lori Parks (Suzan-Lori Parks) (1963), zahvaljujući snazi komičnog, ispitivanju snage jezika, jasnom stavu i osvojenoj Pulicerovoj nagradi za komad Topdog/Anderdog (Topdog/Underdog, 2002). Njena djela obiluju intertekstualnim referencama na američku književnost i istoriju. Kritika posebno ističe jezičku prefinjenost njenog dramskog teksta, rijetku upotrebu jezičkih obrta pomoću kojih uspijeva da snažno obogati sva njegova značenja, pogotovo ironijska. Osim u jeziku, Suzan-Lori Parks eksperimentiše i u formi i piše komad u vidu projekta 365Dana/365Komada (365Days/365Plays) uvlačeći teme iz prethodnih komada, a sa ciljem da se prikazuje po jedan komad dnevno na 
nekoliko mjesta, što je 2006. godine prihvatilo 700 lokalnih i drugih pozorišta. Tematska i jezička provokativnost njenih komada formirala su publiku koja je nestrpljivo u ovoj dekadi čekala svaki njen glas. I još uvijek ga osluškuje. Osluškuje i glasove mnogih pjesnika i pjesnikinja okupljenih oko 9/11.

\section{PoEZIJA}

Ovu dekadu obilježio je jednak odnos snaga američkih pjesnikinja i pjesnika, jer su pjesnikinje pobrale tri prestižne nacionalne nagrade, kao Bolingenovu, na primjer. Tako je 2001. godine za životno djelo dobija Lujza Glik (Louise Gluck) (1943), 2003. Adrijen Rič (Adrienne Rich) (1929-2012) i 2011. Suzan Hou (1937). Nagrađeni pjesnici su: Džej Rajt (1935), Frenk Bidart (1939) i Alen Grosman (Allen Grossman) (1932-2014). Nagrade su uticale na popularnost i ugled pogotovo najprevođenije pjesnikinje, Adrijen Rič, čija je poezija često prevođena na strane jezike, kao i njena ostala prozna djela, a pogotovo njena rasprava o majčinstvu Od majke rodena: majčinstvo kao iskustvo i institucija (Of Mother Born: Motherhood as Experience and Institution, 1976). Njena poezija dala je glas jevrejskoj kulturi, lezbejskim uvjerenjima, feminizmu, ljudima sa posebnim potrebama i starima.

Ništa manje snažno nije se čuo ni glas Lujze Glik koja je govorila u ime porodice, vjere i umjetnosti. Govorila je za sebe da je rođena pjesnikinja, jer je rano počela da piše, a ugled joj je rastao sa svakom novom zbirkom. Počela je sa zbirkama poezije Prvorodeni i Kuća na močvari (Firstborn; The House on Marshland), da bi nastavila da predstavlja svoju viziju svijeta u narednim zbirkama: Figura koja silazi (Descending Figure, 1980) i Ahilov trijumf(The Triumph of Achilles, 1985) i na kraju 1992. godine dobila Pulicerovu nagradu za zbirku Divlji iris (The Wild Iris). Nakon ove zbirke uslijedile su Vita Nova (Vita Nova, 1999), Sedam doba (The Seven Ages, 2001), Oktobar: poezija (October: poetry, 2004), Averno (Averno, 2006) i Seoski život (A Village Life, 2009). 
Džej Rajt je bio prvi afro-američki pjesnik koji se okitio Bolingenovim vijencom, ne samo zbog toga što je tematski povezivao razne svjetove (Čiroki, afro-američki i irski korijeni) u svojim stihovima, već i zbog toga što mu je izučavanje komparativne književnosti omogućilo da uvede veliki broj intertekstualnih referenci. Proveo je neko vrijeme u Njemačkoj i Meksiku, i predavao na Harlemu gdje se upoznao sa značajnim afro-američkim pjesnicima. Govorio je za sebe da je pisac sa kros-kulturnom imaginacijom. Među zbirkama njegove poezije izdvajaju se Pjesnik se vraća kući (The Homecoming Singer, 1971), Dvostruko otkrivanje Koma (The Double Invention of Komo, 1980), Odabrane pjesme (Selected Poems, 1987), Transfiguracije: Sabrane pjesme (Transfigurations: Collected Poems, 2000). Ipak, njegovim najboljim zbirkama savremena kritika proglašava dvije zbirke iz 2008: Polinomijali i polen: parabole, paradigme, i pohvala Loisu (Polynimials and Pollen: Parables, Paradigms, and Praise for Lois) i Otmena umjetnost čitanja odsustva (The Presentable Art of Reading Absence).

Alen Grosman izdvaja se ne samo po poeziji, već i po kritici i pedagoškom radu. On je stekao ugled početkom ove dekade zbirkama poezije Šta raditi sa suzama (How to Do Things With Tears, 2001) i Slatka mladost: pjesme mladića i starca, stare i nove,1953-2001, (Sweet Youth: Poems by a Young Man and an Old Man, 2002). Pet godina kasnije objavljuje Dekartovu usamljenost (Descartes' Loneliness), dok 2009. izlazi zbirka njegovih kritika Istinska-ljubav: eseji o poeziji $i$ vrednovanju (True-Love: Essays on Poetry and Valuing).

Suzan Hou nastavlja da stvara i u ovoj deceniji i postepeno napušta postmodernistički pristup i okreće se američkoj istoriji, što ilustruju njene zbirke poezije Duše Labadi kolonije (Souls of the Labadie Tract, 2007) i Ono ovo (That This, 2010). Kritika smatra da je upravo ovo okretanje istoriji i sloboda koju sebi daje da bi se oslonila na nju, upravo ono što fascinira u njenoj novijoj poeziji. To je njen način da pruži svojim čitaocima glas pjesnikinje koji se nije na taj način čuo ranije: njegovo prisustvo u istoriji i u poeziji.

U ovu grupu možemo uključiti i Bilija Kolinsa (Billy Collins) (1941) koji poput Suzan Hou nastavlja sa svojim stvaralaštvom i nakon zbirki s kraja vijeka Umjetnostcrtanja (The Art of Drawing, 1995) i Izlet, munja 
(Picnic, Lightning, 1998) kada objavljuje zbirku Balistika (Ballistics, 2008). Zasluženo je nagrađen titulom Pjesnik Lauerat (Poet Laureate), koju su nakon njega dobili Lujza Glik, Ted Kuser (Ted Kooser) (1939), Donald Hol (1939), i Čarls Simić (1938). Isto mjesto zaslužuje i pjesnikinja Kej Rajan (Kay Ryan) (1945) sa zbirkama poezije Reci ujače (Say Uncle, 2000), Rijeka Nijagra: Pjesme (The Niagra River, 2005), a naročito zahvaljujući najnovijoj zbirci Od najboljih: nove i odabrane pjesme (The Best of It: New and Selected Poems, 2010).

U prvoj dekadi 21. vijeka, Pulicerovu nagradu dobili su već prepoznati pjesnici, među kojima se izdvajaju Robert Has (Robert Hass) (1941), za zbirku Vrijeme $i$ materijali (Time and Materials, 2007) i Filip Šulc (Philip Schultz) (1945), čija je zbirka poezije Neuspjeh (Failure 2009) ocijenjena jednako vrijednom 2008. godine. Mnogo ranije, 2001, ovu nagradu zasluženo je dobio Stiven Dun (Stephen Dunn) (1939) za knjigu poezije Različiti sati (Different Hours, 2000). Naredne godine Pulicerovu nagradu osvojio je Karl Denis (Carl Dennis) (1939) za zbirku Praktični bogovi (Practical Gods). Izdvojićemo Klaudiju Emerson (Claudia Emerson) (1957-2014), čija je poezija veoma visoko vrednovana, pogotovo njena zbirka Pokojna žena (Late Wife), koja je 2006. nagradena. Naredne godine nagradu dobija, takođe pjesnikinja, Nataša Tretevi (Natasha Trethewey) (1966) za knjigu poezije Domorodačka garda (Native Guard). Pjesnikinje dominiraju do kraja decenije, kada se izdvaja Rej Armantraut (Rae Armantrout) (1947) koja 2010. osvaja Pulicerovu nagradu za zbirku Stihovan (Versed).

Afro-Amerikanku (1966) i njenu zbirku Kućni poslovi (Domestic Work, 2000) promovisala je Rita Dav, koja i sama reaguje na krizu 9/11, odajući počast žrtvama u pjesmi „Umeja: svako od nas se broji" "Umeja: Each of Us Counts", 2003). Naredne godine nova knjiga poezije Nataše Tretevi Beloksova Ofelija (Bellocq's Ophelia) bila je isto tako dobro dočekana. Intertekstualne reference na rat, rasu, militarizam u već pomenutoj zbirci odredile su je kao političku pjesnikinju. Savremena kritika određuje njeno mjesto i među postmodernim pjesnikinjama. Tumačeći snagu njene poezije, neki kritičari upućuju i na elemente biografskog, osjećaj nerazriješenog pripadanja, činjenicu da potiče iz mješovitog braka, što Jug teško prašta. Rej Armantraut do- 
življava sličan uspon kao Nataša Tretevi. Godine 2011. izlazi joj nova knjiga poezije Injekcija novca (Money Shot), dok je Stiven Bert (Stephen Burt) zasluženo uključuje u četiri najznačajnija savremena pjesnika u knjigu Nova književna istorija Amerike (A New Literary History of America, 2009).

Poezija krize 9/11, kako je još neki istraživači nazivaju, ponovo je otvorila jedno staro pitanje: pitanje problematičnog odnosa poezije i politike. Mnogi pjesnici pokušavaju da na njega odgovore, pri čemu se često čuju i pobunjeni glasovi onih koji vjeruju da politika ubija poeziju. U žestokoj debati pobunjenih glasova čuju se i kontra glasovi onih drugih koji smatraju da poezija odgovara na sve aspekte života jedne zajednice, pa i političke. Ona treća, pomirljiva, struja tvrdi da je istina u sredini, jer poezija djeluje kroz jezik koji je u izvjesnoj mjeri i političko sredstvo budući da je u tijesnoj vezi sa našim percepiranjem svijeta i konstruisanjem socijalnog miljea. Ovo znači da su događaji u vezi sa 11. septembrom izazvali pjesnike da se odrede i odgovore i na ono najvažnije pitanje: kako pisati poeziju posle $9 / 11$. Savremena kritika najjasnije prepoznaje ova tri različita odgovora u pjesmi „Kletva” ("Curse”, 2002) Frenka Bidarta, potom u pjesmi „Neko je digao Ameriku u vazduh" ("Somebody Blew Up America”, 2001) Amira Barake i u pjesmi „Alabanca: u slavu lokala 100” (Alabanza: In Praise of Local 100”, 2003) Martina Espade (Martín Espada) (1957).

U pjesmi „Kletva” Frenka Bidarta, savremenoj jeremijadi (dug slobodan stih, postepeno ponavljanje, jednostavan jezik i razvijena verbalna muzika), čuje se poziv na osvetu, osjeća se spoj bukvalnog i nadrealnog dok pjesnik silazi iz svijeta Njujorka u podzemlje u kome mrtvi jedu mrtve, dajući tako glas žrtvama. Najblaži odgovor na traumu je krik traumatizovanih, pokazuje pjesnik, i pretače ga u snažne ritmove ove pjesme. Kletva puna bijesa, to jest osveta, upućena je onima koji su srušili kule bliznakinje.

Frenk Bidart privukao je pažnju čitalačke publike daleko ranije svojom zbirkom poezije, Zlatna država (Golden State, 1973), pogotovo monolozima, da bi 197\%. godine objavio zbirku poezije Knjiga tijela (The Book of the Body). Sledeću knjigu poezije koja ispituje krivicu, Žrtva (The Sacrifice) objavio je šest godina kasnije. Zbirka U Noći Za- 
pada: sabrane pjesme 1965-1990 (In the Western Night: Collected Poems 1965-1990) pojavila se 1990. Kritika posebno ističe pojavu zbirke Želja (Desire, 1997), zbog inovativne upotrebe engleskog i drugih jezika i delikatnog odnosa prema drugim kulturama. Nakon ove zbirke, pojavile su se još tri: Muzika prljavštini slična; Zvjezdana prašina i Posmatranje proljećnogfestivala (Music Like Dirt, 2002; Star Dirt, 2005; Watching the Spring Festival, 2008).

Amiri Baraka u pjesmi „Neko je digao Ameriku u vazduh” koristi fluktirajući slobodan stih, postepeno ponavljanje, jednostavan govor i direktno obraćanje čitaocu. U oko sedam stotina stihova Bidart lajtmotivski koristi riječ „smjeti”, zajedno sa riječju „ko”, da bi reagovao na "teror" u životu Amerikanaca, ali ne samo na terorizam Al-Kaide, i na kontraterorizam Američke vlade, već na teror kao sredstvo moći. „Teror” ima daleko širu konotaciju, odnosi se na državni aparat, mašineriju korporativne kontrole, na sva sredstva pomoću kojih bogati (pojedinci i nacije) pokušavaju da pokažu kako će samo oni naslijediti zemaljsku kuglu. „Neko je digao Ameriku u vazduh” istovremeno povezuje događaje $9 / 11$ sa ciklusom istorije nasilja koji generiše novo nasilje, a koji konstantno kontrolišu ljudi od moći i u Sjedinjenim Državama i van njih, kako u sadašnjosti tako i u imperijalnoj prošlosti. U ovoj pjesmi, Amiri Baraka ovo postiže postavljanjem retoričkih pitanja koja se odnose na vlasnike kolonija, osvajače, vladare svijeta, vlasnike nafte, kradljivce zemlje, da bi na kraju gromoglasno upitao kome je mir potreban, a kome rat. Razrešenje donosi snažna retorika i energija cilja, kao i kod mnogih radikalnih američkih tekstova: bijes, zbunjenost dok osjećaj izdaje zamjenjuje zračak nade. Pjesnik nudi mogućnost pronalaska odgovora na postavljena pitanja, a pogotovo na ono glavno: $k$ o je taj koji se krije ispod tajnih velova prošle i sadašnje istorije.

Treći odgovor na poeziju 9/11 daje Martin Espada u pomenutoj pjesmi „Alabanca: u slavu lokala 100” koji ne unosi neke značajne novine u poetske forme, već slijedi tragove Bidarta i Barake upotrebom slobodnog stiha, idiomatskog govora, postupnog ponavljanja i upornog ritma. Osim toga, kritika primjećuje upotrebu usmene tradicije latinsko-američke kulture i duge vitmenovske stihove da bi odao poštu 
Žrtvama (43) jednog lokala, ljudima koji su izgubili život u napadu na Svjetski trgovinski centar. Espada u ovoj pjesmi definiše mogući kulturološki hibridni „treći prostor”. Pjesma je rijedak spoj elegije i proročanstva, pojedinca i zajednice, bola i pohvale žrtvama i primjer kako lokalni bol postaje globalni sa mogućnošću interkulturalnog dijaloga. Pjesnik prepoznaje nadu u mogućnostima zajednice, jer upravo ona prolazi kroz najjaču krizu. Osim toga, uvođenje terorističkih napada u opjevavanje naroda, zaljučuje kritika, omogućava lakše razumijevanje svakog napada, jer sastavlja fragmente globalnih traumatskih događaja u priču koja ima smisla i daje jedan od odgovora na glavno pitanje: kako pisati poeziju poslije $9 / 11$.

Martin Espada, porijeklom iz Porto Rika, dao je mnoštvo odgovora na svijet i trenutak u kome živi u dvadesetak knjiga ne samo kao etablirani pjesnik, već i kao izdavač, esejista i prevodilac. Dobitnik je mnogih nagrada za stvaralaštvo. Izdvojićemo zbirke poezije koje je objavio u ovoj dekadi: Astronom Maja u Đavoljoj kuhinji (A Mayan Astronomer in Hell's Kitchen, 2000); Alabanca (Alabanza: New and Selected Poems, 2003), Republika poezije (The Republic of Poetry, 2006) i Lopta nevolje (The Trouble Ball, 2011). Mnogi njegovi odgovori odnose se na socijalnu pravdu, borbu za prava Latino-Amerikanaca i povratak istoriji. U visoko ocijenjenim zbirkama poezije on istovremeno proslavlja i oplakuje iskustva imigranata (Porto Riko i Čikano) i radničke klase uvodeći drugost, bespomoćnost i njihovu bijedu u poeziju koja dira u srce dok stvara slike neslavne istorije borbe protiv nepravde i nesreće, čime pogotovo doprinosi podizanju svijesti o kulturološkoj složenosti Amerike.

Izdvojenim pjesnicima krize 9/11 pridružuje se i veliki broj drugih pjesničkih glasova, nagrađenih i nenagrađenih, koji pokušavaju da daju svoj odgovor na 9/11. Značajan doprinos, između mnogih, daju: Majkl Atkinson (1962), Vilis Bernstoun (1927), Mark Irvin (1953), Melisa Altenderfer (1972), Karl Edler (1964), Norman Stok (1974), Robert Krili (1926-2005), Šeli Stenhaus (1968), Andrea Karter Braun (1980), Džin Velentajn (1934), Harvi Šapiro (1924), Miranda Bison (1960), Dejvid Leman (1948), En Lolordo (1970), Aron Smit (1980), Ana Rabinovič (1977), Eliot Kec (1969), Piter Kojot (1949), Katha Pollitt (1949) i 
Niki Mustaki (1967) (Michael Atkinson, Willis Barnstone, Mark Irwin, Melissa Altenderfer, Karl Edler, Norman Stock, Robert Crilly, Shelley Stenhouse, Andrea Carter Brown, Jean Valentine, Harvey Shapiro, Miranda Beeson, David Lehman, Ann Lolordo, Aaron Smith, Ann Rabinowitz, Eliot Katz, Peter Coyote, Katha Pollitt, Nikki Moustaki).

Mnogi od pomenutih pjesnika, ali i oni koje nismo u ovom pregledu posebno izdvojili, odaju počast žrtvama 9/11, zapisuju sjećanja na nepoznate i bezimene, uvode misteriozne tonove, pokazuju izmjenu mjesta vatre ognjišta koja grije i vatre koja spaljuje živote, kretanje od intimnog ka užasnom; neki ukazuju na tijesnu vezu između života i trenutka krize kada, čak i u najmirnijim trenucima, užas rata nije daleko od nas. Držeći se elegijske forme, neki se pjesnici okreću ka istoriji da bi odali počast poginulima: prisutan je često osjećaj da se sve promijenilo. Neki pjesnici slave one rijetke žrtve, čudom preživjele, prepune tuge, dok neki u srušenim kulama prepoznaju vizuelni ekvivalent za traumu, moralni i emocionalni vakuum nakon krize 9/11, koristeći jezik, koji istraživači upoređuju sa verbalnom tapiserijom oplakivanja koja boli zbog onog neizrečenog.

Jezik koji ne može da izrazi ogromnu bol česta je tema poezije krize, pretpostavka da ne može da izrazi užas 9/11: zamjenjuje ga vizuelna praznina, odustvo slike. Vizuelna praznina tema je i nekih pjesnika koji stavljaju akcenat na prazninu doma. Iza površine komemorativne poezije često se skriva osjećaj apokalipse: nad multikulturalnom zajednicom nadvio se crni oblak konflikta, konstatuje književna kritika. Prisutna je nadrealna dimenzija kod mnogih pjesnika, koja pojačava opštu konfuziju i njenu abecedu. Definiše se opšta slika pada sa kula, muškaraca i žena, dok sve ove pjesme povezuje i osjećaj transfiguracije običnog, a vrijeme varira, dok je samo konstantan pad u sjećanje, odsustvo i mrak. Pad prati sumnja, u mnogim pjesmama, da su teror i kontrateror odrazi u ogledalu jednog te istog, što znači da je znanje bespomoćno, pokazuju neki pjesnici, jer ljudi od moći kontrolišu događaje i slijede logiku rata, dok nasilje generiše novo nasilje. Prizivaju se slike ratova iz prošlosti Amerike i svijeta i porede sa 9/11, isključujući mogućnost povratka u sigurnost toplog doma, što negira svaku nadu u spas pojedinca. 
U nekim post-9/11 pjesmama može se pratiti kako očaj prelazi u bijes i budi vjeru da pjesnik može da promijeni svijet, jer on mora da progovori o istini jezikom običnog čovjeka, da poduči o čemu se u svijetu zapravo radi, zbog čega se u pomoć često priziva Vitmen. Lajtmotivski se postavlja glavno pitanje: kako pisati poslije $9 / 11$ da bi se konačno prepoznala sumnja u sve, jezik, publiku, pjesnički glas. Sumnja generiše paranoju kod nekih pjesnika, dok je prisutan napad na ljude od moći koji stoje iza 9/11, zbog čega se riječi koriste kao oružje, kao jedino sredstvo koje stoji na raspolaganju nemoćnima. Ono najbolje što se može prepoznati u korpusu poezije $9 / 11$ (elegijske, lirske, deklamatorne ili nadrealne), jeste snaga pjesnika da predstave krizu ne preispitujući uzroke i posledice, već ispitujući doživljaje pojedinaca. Poezija 9/11 nudi niz verbalnih ekvivalenata ličnim susretima sa traumom, što je i jedini mogući pjesnički odgovor na pitanje kako pisati posle 9/11, odgovor koji nije ništa drugo do upućivanje na nastavak već definisane tradicije u američkoj književnosti.

\section{IZVORI I CITIRANA LITERATURA}

ELLIOTT, Emory (ed.). The Columbia Literary History of the United States. New York: Columbia University Press, 1988.

ElLiotT, Emory. The Columbia History of the American Novel. New York: Columbia University Press, 2004.

GRAY, Richard. A History of American Literature. Oxford: Blackwell, 2012.

Hammond, Adam. Literature in the Digital Age, Cambridge University Press, 2016.

Jones, Gavin. Failure and the American Writer: A Literary History. Cambridge University Press, 2014.

KeITH, Brianne. American Lit101. Avon, MA: Adams Media, $201 \%$.

KLARER, Mario. A Short Literary History of the United States. London and New York: Routledge, 2013.

MaRTin W. and Williams S. The Routledge Introduction to American Women Writers. London and New York: Routledge, 2016.

Miller, D. Quentin. The Routledge Introduction to African American Literature. London and New York: Routledge, 2016. 
Nealon, Jeffrey T. Post-Postmodernism or, the Cultural Logic od Just-In-Time Capitalism. Palo Alto: Stanford University Press, 2012.

O'Donnell, Patrick. The American Novel Now: Reading Contemporary American Fiction Since 1980. Chichester: Wiley-Blackwell, 2010.

Radonjuć, Goran. Fikcija, metafikcija, nefikcija. Beograd: Službeni glasnik, 2016.

Savvas, Theophilus. American Postmodernist Fiction and the Past, London: Palgrave Macmillan, 2011.

Wagner-Martin, Linda. A History of American Literature: 1950 to the Present, Chichester: Wiley-Blackwell, 2013.

Radojka Vukčević

AMERICAN LITERATURE AFTER 9/11 - LITERATURE OF "CRISIS”

Summary

The paper will focus on the first decade of the XXI century, the period in the history of American literature which has been defined as the period of "crisis" or the period of $9 / 11$ owing to the attacks on the World Trade Center, and pain the people experienced thereafter. The pervasive images used to describe $9 / 11$ will be presented. The fusion of the real and the symbolic will be analyzed through the metaphors which enact emotional states. This will be followed through different genres: stories, drama, poetry, memoir and Life-Writing, and fiction.

Keywords: 9/11 images, drama, poetry, memoir, Life-Writing, fiction.

Univerzitet u Beogradu

Filološki fakultet

vukcevicradojka@gmail.com 